\title{
Managing Risk Integration for Performance Orientation among Malaysian Firms
}

\author{
Michael Tinggi ${ }^{1}$, Shaharudin Jakpar ${ }^{1}, \mathrm{Ng} \mathrm{Kim} \mathrm{Hui}{ }^{1}$ \\ ${ }^{1}$ Department of Accounting and Finance, Faculty of Economics and Business, Universiti Malaysia Sarawak, \\ Malaysia \\ Correspondence: Michael Tinggi, Department of Accounting and Finance, Faculty of Economics and Business, \\ Universiti Malaysia Sarawak, 943000, Sarawak, Malaysia.
}

Received: October 18, 2018

Accepted: December 18, 2018

Online Published: December 24, 2018

doi:10.5539/ibr.v12n1p119

URL: https://doi.org/10.5539/ibr.v12n1p119

\begin{abstract}
The study is potentially, to explore the effect of discounting for risk on performance of firms listed in Malaysian stocks' market. Risk management has been part of the corporate philosophy in maximizing shareholders' wealth and firms' profit. Managing risk cannot be done in isolation. Too often common risks pertinent to operation, liquidity and financing may be taken for granted by many firms. Risks exist on stand alone, but its implication may negatively severe firms' performance if not addressed or dealt with properly. Integrating and managing risks may potentially improve the quality of business processes, which may orientate towards attaining firms' performance at the corporate level. The 2007 global financial crisis has incidentally highlighted the importance of integrating and managing risk and its effect on business. Empirical evidences from the Panel Random Effect (RE) analysis of the above companies showed that the firm's ability to manage and integrate operating, liquidity, and financial risks steer the firms towards performance orientation.
\end{abstract}

Keywords: managing risk, integrating risk and performance orientation

\section{Introduction}

\subsection{Background}

Risk is quite often being associated with uncertainty of a future outcome. The risks that the firms encounter are often multifaceted, complex and interlinked. Managing risk cannot be done in isolation. Risks may exist on stand alone, but it may bring about severe negative bearing if not addressed properly. Board of directors and other senior executive managements of the company are expected to be responsible enough, to ensure that risks are being mitigated seriously. In the current turbulent business environment, there is a greater responsibility for risk management issue to be put in place properly. Risk is the possible outcome of uncertainty. Business activities are affected by factors such as strategic, operational and financial failures, market disruptions, environmental disasters, and regulatory violations. Firms would normally take appropriate level of risk in order to earn adequate returns. The more common type of risks are market risk and unsystematic risk including liquidity risk, financial risk, and operational risk that may be affecting business performance. The global financial crisis, which occurred in 2007-2008, highlighted the impact of ignoring risk, when US market and the worldwide financial system suffered biggest financial turbulence. The collapse of Bear Stearns and Fannie Mae and Freddie Mac, the fall out of the Lehman brothers and the disposal of Merrill Lynch have brought about much instability to the international financial market. The financial meltdown has highlighted the importance of risk management and its effect on business. Risk management is indeed a process of identifying, quantifying, and managing uncertainty. Essinger \& Rosen (1991) and Mohsen, Arezoo, \& Vahid (2011) define risk management as an effective tool to minimize any undesirable risky effects which may potentially maximize the benefits of the risky situations. Risk management is a relatively recent corporate philosophy with the objective of maximizing shareholder wealth while minimizing the uncertainty faced by the business. Excessive risk may increase business uncertainty, which will bring about lower returns or even cause corporate default to the organization. Therefore, firm should manage certain risk that is more or less corresponding to the firm strategic action in order to create value to its shareholders and the firms' performance.

The current global business environment is exerting more pressure on the need to continuously improve the corporate performance. No matter where and what type of business the industry is embarking on, the same 
common risks such as liquidity risk, financial risk, operational risk, market risk, and credit risk are bound to be encountered. Every risk has its own degree of impact on the firm performance. In the daily operation of the firm, risk will certainly have a direct or indirect impact on the value and earnings of the firm or the liquidity available. Operational risk may be tangibly seen in the likes of business disruption, loss and failure of business. Claus and Daniel (2012) defined operating risk as the possibility of losses resulting from failure, inadequacy and insufficiency of internal processes, people and systems.

Good operational risk management can help in minimizing risks for quality improvement and cost reduction, consequently creating competitive advantages and improve business efficiency (Claus \& Daniel, 2012).

The firm may hold sufficient liquid assets or surplus of cash in order to meet daily operating and financial obligations. A successful business, will position the firm to get the right balance of liquid's asset, which can neither be too excessive nor too little to meet their short term obligations. A firm suffering from temporary or permanent disruption or shortage of cash demonstrates that the firm is experiencing liquidity problem, a symptom for facing liquidity risk. Liquidity risk is the risk to an institution's financial condition or safety from its inability to meet its contractual obligations. Liquidity risk may result from the inability to quickly sell a financial asset at a value close to its fair value (Arthur, 2013). Managing liquidity risk allows firm to keep sufficient cash anytime to ensure that funds are available when the need arises. The strength of the company liquidity position can be determined by evaluating its level of current assets. Excessive level of current assets could also mean idle assets have taken place and may have a negative impact on the firm's profitability as it is not efficiently utilized. A low level of current assets may portray a lower level of liquidity, signaling a sign that additional funds are needed, thus effectively would help to maintain smooth business operations (Horne \&Wachowicz, 2001).

Capital is the lifeblood for every organization. Organizations always strive for optimal capital structure during the process of raising capital, in order to maximize revenue for the firm. The firm can either choose debt financing or equity financing or preferred stock in funding the firm's operation and asset acquisition. The level of financial risk imposed on the firm is dependent on the company's financial structure. Certainly the firm would like to use debt financing if it would lead to a tax shield benefit, thus improving firm's profitability. Increase in debt capital by the company may incidentally increase firm's exposure to financial risk, such as increase likelihood of bankruptcy and rising cost of capital for future borrowing, and thereby weakening the firm's ability to provide adequate return to its shareholders. The firm should therefore use debt capital with caution to avoid financial distress and reduce additional debt stress at minimum cost, in times of crisis. Any excessive debt will expose the firm more, to financial risk and distress, especially when the firm encounters difficulty in meeting both immediate and short-term obligations. Therefore, the management should examine the level of debt and leverage of the firm in order to reduce future uncertainty.

\subsection{Research Objectives}

The recent financial market meltdown has highlighted the importance of risk management in protecting and creating shareholder's value. Being able to manage risk in business is certainly part of good corporate governance. Since risk management is to protect against the downside risks, managing volatility among businesses may improve financial results. Therefore, risk management should be holistic, predictive, and relevant to the operating model of business. A successful company is more likely to include risk management as a key input in making organizational decisions. Given a scenario, when a firm incurs heavy debt from its supplier, it will bear the consequence of a high financial risk, such as encountering difficulty to pay off its debt. The suppliers that are constantly not being paid on time may retaliate and will not be willing to supply on credit to the firm anymore, causing disruption to the firm's working capital management. In the long run, it may have a downward impact on business performance, as production or service input is affected. It is important that they will properly understand and manage risk in the context of the overall corporate strategy. When designing the corporate strategy, the firm must consider seriously the implication of managing risk. Today, operating and financial performances are the main areas of concern for the firm. The firm must be able to meet its both short-term and long-term liability in the form of interest and principal payments on its debt. The firm must continue to be solvent and operating as a going concern. On top of this, operating efficiency also cannot be discounted in order for firm to enjoy sustainable profit. Finally, a firm with a strong liquid position should have enough cash to meet its immediate and long terms obligation. Firm that holds insufficient cash may resort to additional borrowing. This may prove to be costly and that may contribute to higher operating cost from higher cost of borrowing. So in the light of the above discussion, it is quite imperative that the firm should have some serious view on integrating its operating risk, liquidity risk, and its financial risk in order for the firm to orientate itself towards maximizing its performance. 
Three broad objectives are identified.

First, is to assess if putting an effort in managing operating risk may orientate firm to improve on its performance;

Second, is to evaluate, if managing liquidity risk is significant for firm performance; and,

Finally, by being able to put emphasis on its financial risk during the process of seeking additional funding, may orientate the firm towards improving its performance.

\section{Literature Review}

The study is indeed motivated by some of the underlying theory. First, the theoretical explanation of risk management behavior is the maximization of the private utility of managers itself in agency theory. The theory explains that management will act in their own best interest to increase their personal wealth at the expense of the owners of the organization. Managers may assure business risk that would only satisfy themselves and not the shareholders. Thus, the managerial incentives of risk management may not be beneficial to shareholders and may decrease firm value. In a study by Anup and Charles (2012), when managers' incentives are not aligned with its shareholders it will create an agency problem between them which may result in lower profit for the organization. Moreover, a highly contingent and long term incentive contract which are granted to align manager's interest with those investors, are instances of causing operating cost to rise even further. Second, the theory on financial distress is first derived by Smith and Stulz (1985), which holds that, by reducing the likelihood of costly financial distress, risk management can increase the debt capacity that can increase the expected value of the firm. The firm can benefit from the valuable tax shield or reduction in agency costs with excess free cash flow. Hence, managing the risk can reduce the volatility of the financial distress such as bankruptcy costs. This will benefit the shareholders from rising firm's value. Nevertheless, the benefit of free cash flow is not often felt, as increase exposure to financial risk from additional borrowing is putting pressure on firms' liquidity position.

Third, the theory on enterprise risk management (ERM) acts as an aligning strategy, processes, technology, and knowledge, which is used to evaluate and manage the enterprise due to the uncertainties faced by them. It is an emerging model that is truly holistic, integrated, forward-looking, and process-oriented approach in managing all business risk and opportunities, with the intention of maximizing shareholders' value. (Stephanie, 2009). It is clearly known that the importance of identifying and proactively addressing risks more strategically will achieve the expected shareholder value. ERM allows firm to seize opportunities to identify and assess capital needs more effectively and improve capital allocation (COSO, 2004). This will then improve the firm performance in term of shareholder wealth maximization. Stulz $(1996,2003)$ argues that in risk management, it is mainly focused on the reduction or elimination of "costly lower-tail outcomes" that will potentially create value for the firm. The lower tail outcomes can be subdivided into direct costs (bankruptcy costs) and indirect costs (loss of reputation) which are primarily known as the negative earnings and cash flow shocks. He also argues that if the risk management can reduce the likelihood of negative earnings shocks (direct or indirect costs) and financial distress, then it will definitely create value to its shareholders. ERM takes a holistic view of risk management to reduce the probability of large negative earnings and cash flows by coordinating, controlling and offsetting risks across the enterprise. Finally, the capital structure theory on interest as a tax shield allowance by Modigliani and Miller (1963) also suggested it seems to be more beneficial for the company to take up loans than the equity financing. This is because the cost of borrowed capital is a tax-deductible allowance, while the cost of equity is not tax deductible. Therefore, a company relying more on debt would tend to get more tax saving. Therefore, the $100 \%$ optimal debt financing will increase the firm value as debts increase. However, the excessive indebtedness may lead to over exposure to a plausibility of not being able to meet its financial obligation when the debt falls due, thereby increasing its financial risk

Successful firms often have an effective internal control system that will best position itself against business operation failure, while driving value creation to its shareholders. Internal control is the operational strategy of an organization's governance system and its ability to manage the risk at the top management level in order to meet the organization's objectives. Effective internal control can actually save time and money and definitely will increase the operational efficiency. While increasing revenue is constantly sought, firms are also looking at opportunities to minimize costs. Managers are advised to take a closer view on firm's fixed, variable, and total costs of production that is related to sales volume in order to earn above average returns. Identification of the component fixed cost helps manager to manage the firm with desirable profit at the minimum operating cost. These fixed costs include utilities, contracted services, operation fees, insurance, employee benefits, lease and credit payments and other such disbursements such as rent, training, and depreciation. It is realized that all firms 
have some fixed costs that must be paid no matter how many products are sold. Variable and direct costs will continue to be optimized, without compromising with the quality of the services and products that are being delivered. Reducing these costs can be challenging, but can also lead to the greatest long-term savings for a company. By identifying and controlling these fixed and variable costs, the firms are better able to earn profit sustainably. While variable costs are more controllable it is not that easy to manage fixed cost especially in the short term. In certain industry like airline and hotel, fixed costs are more difficult to manage. Toh and Raven (2003) mentioned that, for a firm like airline, which is operating with high fixed costs should increase occupancy by decreasing price during lean period, and to increase revenue by increasing price during peak period with the overall objective of increase in profits. As operating risk partially arises from fixed cost, (Braun and Tietz, 2015) for the management to minimize the operating risk, it has to manage the fixed costs during the accumulation of costs at the point of cost of sales.

The liquidity position is important to the firm performance and might influence the organization's profitability. It principally has an effect on financial costs reduction or growth, changes in the sales dynamic, as well as influences on company risk level. Chamberlain and Gordon (1989) claimed that company's decision on liquidity will considerably determine the company's achievement. Jose, Lancaster and Stevens (1996) opined that liquidity management is important for firm to achieve profitability and good performance. Padachi (2006) found evidence of a positive impact of the firm's liquidity on profit. Too much liquidity by inefficient use of funds can have an unfavorable effect on the firm's business operations and profitability, especially when too much funds are tied up in non-income generating short term investment (Horne and Wachowiz, 2001). On the other hand, firms with insufficient liquid assets as shown by low level of current assets may have difficulty in continuing operations, as it may experience difficulty in meeting its day to day obligation. In a study by Qasim and Ramiz (2011), companies usually do not think about improving liquidity position, before finding themselves reaching financial crisis or on the verge of bankruptcy. In managing liquidity, company often uses the current ratio and quick ratio to measure the level of liquidity in the firm. The level of current ratio expresses the company's ability to pay its debts in short time. It is important to maintain current ratio at certain level to ensure that the firm is able to pay its current debt obligations without delay.

Financial risk associated with the company's financial structure depends on the manner of funding of the business activity either by debt or equity or both, may have overall impact on the profitability of the company. It is often known that the optimal capital structure of a firm is quite related directly to the right mix of the weighted average cost of capital (WACC). Some companies could be all equity-financed with no debt at all, while others could be financed by low levels of equity and high levels of debt. Kinsman and Newman (1998), Majumdar and Chhibber (1999), Eriotis et al. (2002), Ngobo and Capiez (2004), Goddard et al. (2005), Rao et al. (2007), Zeitun and Tian (2007) and Nunes et al. (2009) found that those firms with lower debt or no debt can maximize their firm value. Hence, the theory which says that the firms should use relatively less debt to finance their assets and use relatively more equity to finance the growth opportunities, (Hovakimian, Opler, and Titman, 2001) is actually in contrast to the early theory of capital structure from Modigliani and Miller (1963) which views that debt capital is more cost effective as interest expenses would shield the firm from paying high corporation tax.

It is clearly stated that three components affecting the firms' performance discussed above, which are the financial, liquidity, and operational activities are important for firm, in order to remain profitable and subsequently increasing shareholder wealth. Therefore, the top level executives or decision makers should be aware of the above impact on business performance and to take immediate action when the organization and financial objective are not met. Thus, effective risk management is important in the sense that it gives a clear picture on how the business is being run. This can help the firm to minimize the impact of business risk and uncertainty.

\section{Research Methodology}

The study highlights essentiality not to ignore business risks. If the risks are managed properly, there is a good likelihood that the firm would orientate itself towards improving firm's performance. The secondary panel data is randomly selected from the annual report comprising industry from trading services and consumer sector of the public listed firms in Malaysia for period from 2005 until 2012. The reason for choosing period from 2005 to 2012 is to give sufficient time for all firms to restructure themselves from the effect of operating and financial risk that were beset by the Asian financial meltdown, in 1997/1998 and the corporate governance crisis in 2000/2001. An estimated 100 public listed firms in the trading services and consumer sector were picked heralding the operational, liquidity, and financial aspect of risk. To measure risk effect, a proxy is identified to represent each exogenous variable. Figure 1 below summarizes the conceptual framework, while table 1 below summarizes the proxy for each of the exogenous variables. The risks such as operating risk, liquidity risk and 
financial risk are mainly related to the business operation. These types of risks have to be managed well in order that the impact of ignoring risk shall be minimized or avoided. Cost of goods sold (COGS) is used to measure operating risk. Operating risk is a form of risk that will potentially threaten company to suffer loses or reduction in profit. COGS can be in the form of fixed, variable costs or mixed of both costs. Fixed cost is more difficult to manage and control. High fixed cost would lead to high COGS, and could bring about lowering in profit. Fixed cost that is effectively utilized, will increase profit.

In managing liquid assets, company often uses current ratio and quick ratio to measure the level of liquidity of the firm. The level of current ratio expresses the company ability to pay its debts in short time. Maintaining current ratio at a certain level is vital to ensure that the firm is able to pay its current debt and obligations without delay. When current ratio decreases, it would send a signal that the company profitability has deteriorated, thus reducing the firm's performance in maximizing its shareholder's value. Vice versa higher current ratio shows that the firm will be in a healthy state of affair.

Financial risk detected, may be regarded as a sign of over exposure to debt and may demonstrate the firm's difficulty to meet debt obligation. Financial risk can be measured by using debt to equity capital ratio. When more debt capital is used, the firm will increase its exposure to financial risk. Any future borrowings may cause the cost of debt capital to be less cost effective, and certainly will put pressure on firms operating income. A study by Hovakimian, Opler, and Titman (2001), contradict the early theory of capital structure developed by Modigliani and Miller (1963) who view that debt capital is more cost effective, as interest expenses shield the firm from paying high corporation tax. In most cases, when firms have higher debt capital, the cost of borrowing would outweigh the benefit of interest expense shielding the company from paying too much tax. In other words, it will become less cost effective if debts capital keeps on increasing.

Finally, the firm's performance is the endogenous variable in this study. To measure the firm performance, return on asset is used as a proxy, and, is calculated as "net profit divided by total assets". (Demsetz and Lehn, 1985; Gorton and Rosen, 1995; Mehran, 1995; Rao et al, 2007; Zeitun and Tian, 2007)

In this case, it is finally formulated that the return on assets ratio, which is a proxy for firm performance is a panel function of cost of goods sold, a proxy for operating risk, current ratio for liquidity risk, and finally debt ratio for financial risk.

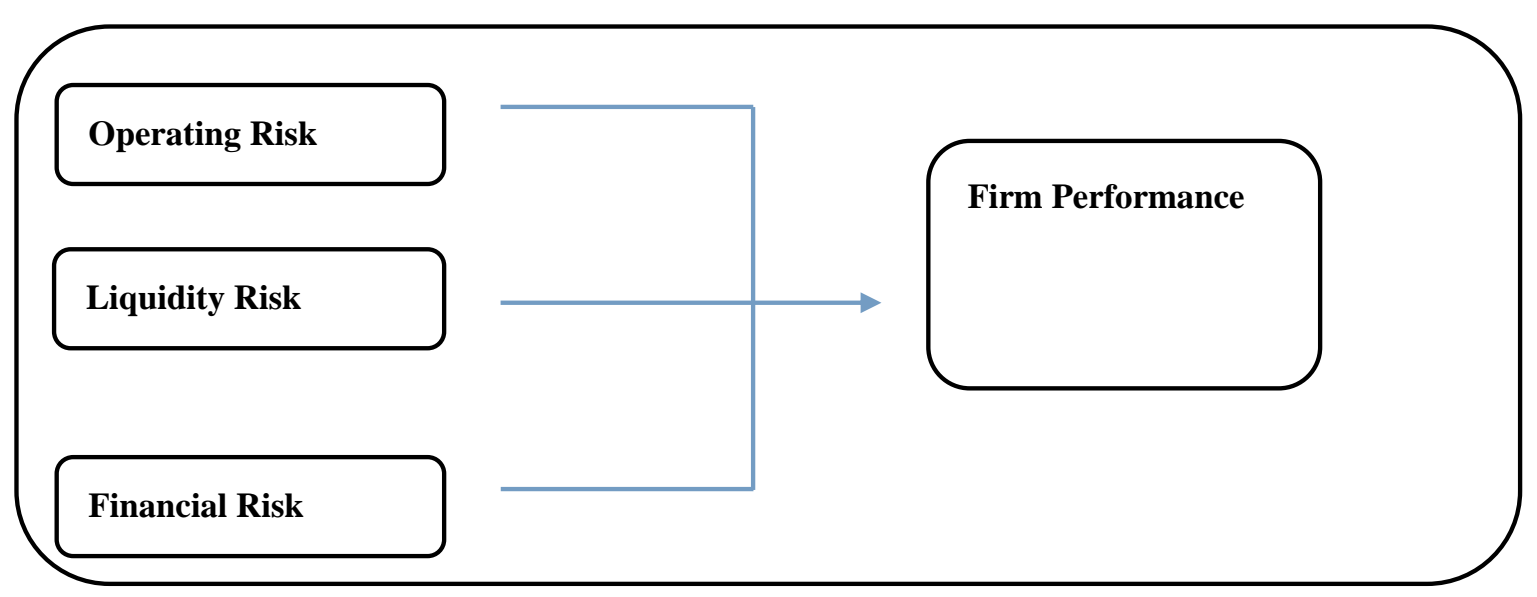

Figure 1. Summary of Conceptual Framework

Table 1. Summary of the Exogenous Variables and its Proxy

\begin{tabular}{cc}
\hline Exogenous Variables & Proxy \\
\hline Operating Risk & Cost of Goods Sold \\
Liquidity Risk & Current Ratio \\
Financial Risk & Debt-to-equity Ratio \\
Firm Performance & Return on asset (ROA) Ratio \\
\hline
\end{tabular}

For this study, the general functional form is constructed to describe the relationship between operating risk, liquidity risk, and financial risk and firm performance.

$$
\mathrm{FP}=f(\mathrm{OR}, \mathrm{LR}, \mathrm{FR})
$$

where, 
FP : Firm Performance;

OR : Operating Risk;

LR : Liquidity Risk; and

FR : Financial Risk.

From the functional form above, it can be explained that the firm performance (FP) is a function of operating risk (OR), liquidity risk (LR), and financial risk (FR). Based on the functional form,

an empirical model is constructed from the conceptual framework discussed in the previous part. The equation can be expressed as follows:

$$
\mathrm{FP}_{\mathrm{it}}=\beta_{0}+\beta_{1} \mathrm{OR}_{\mathrm{it}}+\beta_{2} \mathrm{LR}_{\mathrm{it}}+\beta_{3} \mathrm{FR}_{\mathrm{it} 3}+\varepsilon_{\mathrm{it}}
$$

where,

$$
\begin{aligned}
\multicolumn{1}{c}{\beta} & : \text { is the parameters/ slope coefficient; } \\
\mathrm{FP}_{\text {it }} & : \text { Firm performance of firm i at time } \mathrm{t} ; \\
\text { ORit } & : \text { Operating risk of firm } \mathrm{i} \text { at time } \mathrm{t} ; \\
\text { LRit } & : \text { Liquidity risk of firm } \mathrm{i} \text { at time } \mathrm{t} ; \\
\text { FRit } & : \text { Financial risk of firm } \mathrm{i} \text { at time } \mathrm{t} \text {; } \text { and, } \\
\varepsilon_{\mathrm{it}} & : \text { error term. }
\end{aligned}
$$

The study examines the relationship of the exogenous and the endogenous variables by means of Pearson Correlation and a static panel data. The latter is preferred to a dynamic panel as there is no strong evidence to demonstrate the theoretical presence of a lagged variable. In panel data analysis, a pooled OLS or known as constant coefficient regression model is used to pool the large observations from time series and cross-sectional observations. This method is employed by assuming that all the regression coefficients are homogenous whereby the error term has zero mean and constant variance. There is a possibility that the error term may be correlated with some of the regressors in the model. If this is the case, then the estimated coefficients are said to be bias, and inconsistent. Hence, random effects (RE) model and fixed effects (FE) model should be tested for an alternative model to be adopted.

The choice for the right model will be determined by Breusch and Pagan Lagrangian Multiplier (LM) Test,

$$
\text { (LM) Test, } L M=\frac{N T}{2(T-1)}\left[\frac{\sum_{i=1}^{N}\left[\sum_{t=1}^{T} \hat{\varepsilon_{i t}}\right]^{2}}{\sum_{i=1}^{N} \sum_{t=1}^{T} \hat{\varepsilon_{i t}^{2}}}(-1)\right]^{2}
$$

which will aid to discriminate between a panel RE regression and a simple Ordinary Least Square (OLS) regression. The null hypothesis in the LM test is that variance across entities is zero, $H_{0}: \sigma_{\lambda}^{2}=0$ where the alternative hypothesis is $H_{1}: \sigma_{\lambda}^{2} \neq 0$. Failure to reject the $H o$ indicates that the variance of the error term is constant and the model will experience a Best Linear Unbiased Estimates (BLUE) and thus the OLS model is assumed to be more efficient. To select between the RE and the Fixed Effect (FE) model, a Hausman test,

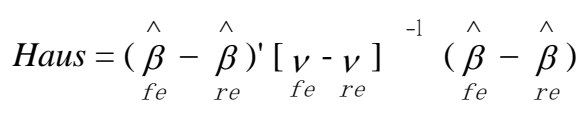

will be conducted. The test is to assume the country specific effects, are either correlated or uncorrelated with the regressors. The null hypothesis is formulated as, $H_{0}: \operatorname{Cov}\left(\lambda_{i}, x_{i t}=0\right.$, where the alternative $H_{1}: \operatorname{Cov}\left(\lambda_{i}, x_{i t} \neq 0\right.$. The random effect estimator, will deliver a consistent estimator that is efficient, otherwise it will be biased. Failure to reject the $\mathrm{HO}$ indicate that the country specific effect does not correlate with regressor, indicating that the RE model is more efficient. If, that is the case, the RE model will be selected over the FE model.

Subsequently several tests are carried out in the panel regression. The t-test is used to test the hypothesis of an individual regression coefficient. A test for evidence of significant statistic is a procedure by which sample 
results are used to verify the validity of a null hypothesis. The t-test statistic is defined as: $t=\frac{\widehat{\beta 2}-\beta 2}{s e(\widehat{\beta 2})}$ where, $\beta_{2}$ is the estimator of the true population parameter $(\beta)$ and $s e(\widehat{\beta 2})$ is the standard error of $\beta_{2}$. Diagnostic checking such as testing for the present of serial correlation, heteroscedasticity, and multicollinearity is done in order for a model to be best linear unbiased estimator (BLUE). We use Modified Wald Test for the robust standard error to address the problem of heteroscedasticity that exist in all three of the models. We then test for autocorrelation between the error terms by using Wooldridge Test. It is assumed that there is no first order autocorrelation between the error terms if we do not reject the null hypothesis with the p-value more than $5 \%$. If the p-value is less than 5\%, it means that we are rejecting the null hypothesis and accepting the alternative hypothesis that there is first order autocorrelation in the error terms. Lastly, we also test for the multicollinearity among the independent variables. If the variance inflation factor (VIF) is greater than 5, it means that there is multicollinearity problem in the independent variables.

\section{Findings and Discussion}

Table 2 below provides a summary of descriptive statistics of the return on assets (ROA), cost of goods sold (COGS), current ratio (CAR), and debt-to-equity ratio (DER) which representing the dependent and independent variables in the study. The data is converted to natural logarithm to ensure that the result for the study is more reliable. The sample firms are taken from trading and consumer services industry listed on Bursa Malaysia for the period 2005 to 2012. From the table the mean ratio for the return on assets (ROA) as the dependent variable has a negative value of $-2.73 \%$ and varies from $-4.61 \%$ to $0 \%$. On the other hand, COGS has the highest mean ratio of $19.01 \%$, which varies from $13.59 \%$ to $24.18 \%$ among the independent variables. This is followed by CAR with the mean ratio of $0.79 \%$ ranging from $-1.08 \%$ to $4.95 \%$. The DER has the lowest mean ratio of $-0.65 \%$ that is varies from $-4.61 \%$ to $3.26 \%$. In general, the low mean value demonstrates that overall, little changes have occurred. The standard deviation for the COGS is 1.75, which is the highest, followed by DER, return on assets (ROA) and CAR with $0.92,0.79$, and 0.72 respectively. The overall standard deviation for this study is low and thus there is a low variance among the independent variables. The low standard deviation and variance indicate that the data is consistent and stable that will produce a more reliable result.

Table 2. Summary of descriptive statistics of dependent and independent variables

\begin{tabular}{lccccc}
\hline Variables & Observations & Mean & Std. Dev. & Min & Max \\
\hline LROA & 698 & -2.727523 & 0.7889693 & -4.60517 & 0 \\
LCOGS & 808 & 19.01227 & 1.750778 & 13.58986 & 24.17617 \\
LCAR & 808 & 0.7874191 & 0.7164698 & -1.07881 & 4.94734 \\
LDER & 806 & -0.6496454 & 0.9203664 & -4.60517 & 3.258096 \\
\hline
\end{tabular}

4.1 Correlation Coefficient Test

The Pearson Correlation as per table 3 below is used to measure how strongly the variables are related or associated with other. The covariance between dependent variable and independent variables shows the relationship between the two variables, which are either positively or negatively correlated. However, the test does not give any idea on how strongly the two variables are correlated. It does provide the notion that if the correlation is closed to +1 , it means that the dependent variable and independent variable are strongly and positively correlated. If the correlation is closed to -1 , it indicates that the there is a strong negative relationship between the two variables. If the correlation is close to zero, the two variables are not in any way related. The result above indicates a significant and positive correlation between ROA and COGS and CAR at the 5\% and 1\% significant level respectively. It certainly shows that the COGS and CAR are moving in similar direction with the ROA. In other words, when the operation and the solvency of a firm are managed efficiently it may result in increasing firm's performance in term of profitability. In Toh and Raven (2003) study, the firm should maximize the utilization of its high fixed costs to full capacity in order to reap maximum revenue. A positive relationship between ROA and CAR is consistent with the study done by Padachi who opines that there is a positive relationship between liquidity and the firm's profitability (Padachi, 2006). Another study by Larsson and Hammarlund (2007) suggests that good liquidity management is important to achieve better profit margins and higher turnover ratio, which will lead to higher profitability. On the other hand, there is a significant and negative relationship between return on assets ROA and DER at $1 \%$ significant level. This result is consistent with the findings done by Majumdar and Chibber (1999) that debt equity ratio is negatively and significantly related to performance as shown in the regression results. The firms with higher debts will normally result in low 
profitability for the firm. This is consistent with the findings done by Kinsman and Newman (1998) that firm with lower debts or no debt can maximize their firm profitability and firm value.

Table 3. Pearson correlation between the dependent variable and independent variables

\begin{tabular}{ccccc}
\hline & LROA & LCOGS & LCAR & LDER \\
\hline LROA & 1 & & & \\
LCOGS & 0.0878 & 1 & 1 & \\
& $(2.3568)^{* *}$ & & & \\
LCAR & 0.2110 & -0.3027 & -0.6829 & 1 \\
& $(5.7719)^{* * *}$ & $(-8.4919)^{* * *}$ & $(-25.002)^{* * *}$ & \\
\hline
\end{tabular}

1. Figures in the parenthesis are t-statistic.

2. Coefficient level: $10 \% *, 5 \% * *, 1 \% * * *$

\subsection{Panel Regression}

Table 4 below shows the summary of the panel data analysis. All the three models which are the OLS Pooled Model (OLS), Fixed Effects Model (FE), and Random Effects Model (RE) are tested for selection criterion. To find the appropriate model first, the Breusch Pagan LM Test is tested to choose between OLS Pooled Model and Random Effects Model. The Breusch Pagan LM Test, recorded chi-square value of 425.23, with its $\mathrm{p}$ value $=$ 0.000 which is significant at $99 \%$ confidence level. Thus the null hypothesis of pooled OLS is rejected while accepting the more appropriate alternative model in RE. Next is the selection between RE and FE model by running Hausman test to determine if there is any correlation between the specific error terms and the regressor. Hausman test gives evidence of low chi-square value of 1.81 and $p$ value of $0.6130>0.01 \& 0.05$ confidence level. The Hausman Test reveals that the null hypothesis of $\operatorname{cov}\left(\lambda_{\mathrm{i}}, \mathrm{x}_{\mathrm{it}}\right)=0$ is present, indicating that the random effects model is appropriate and more efficient. As the random effects model is run on the generalized least square (GLS) method and it will be robust to the threat of heteroscedasticity problem. Nevertheless, the test for the existence of autocorrelation between the error terms is necessary by using Wooldridge Test. From table 4, the p-value of 0.1713 , which is greater than any given significant level, shows that the null hypothesis of constant error terms cannot be rejected. It shows that there is no first order autocorrelation in the model and can be said that the error terms are serially independent. Lastly, table 4 also shows the value of variance inflation factor (VIF) for test of multicollinearity of the independent variables in COGS, CAR and DER with VIF values at 1.13, 2.12, and 2.14 respectively. The overall mean of VIF of $1.18<5.0$ is small, indicating that there is no presence of multicollinearity among the independent variables.

Table 4. Summary of the panel data analysis

Independent Variable: Return on assets (ROA)

\begin{tabular}{|c|c|c|c|c|}
\hline & $\begin{array}{l}\text { OLS Pooled } \\
\text { Model }\end{array}$ & $\begin{array}{l}\text { Random } \\
\text { Effects } \\
\text { Model }\end{array}$ & $\begin{array}{l}\text { Fixed } \\
\text { Effects } \\
\text { Model }\end{array}$ & VIF \\
\hline Constant & $\begin{array}{c}-4.678335 \\
(-13.23)^{* * *}\end{array}$ & $\begin{array}{l}-4.242268 \\
(-7.42)^{* * *}\end{array}$ & $\begin{array}{l}-3.180459 \\
(-2.97)^{* * *}\end{array}$ & - \\
\hline LCOGS & $\begin{array}{l}0.088307 \\
(4.97)^{* * *}\end{array}$ & $\begin{array}{l}0.066404 \\
(2.26)^{* *}\end{array}$ & $\begin{array}{l}0.013723 \\
(0.25)^{*}\end{array}$ & 1.13 \\
\hline LCAR & $\begin{array}{l}0.222654 \\
(3.77)^{* * *}\end{array}$ & $\begin{array}{l}0.177335 \\
(2.76)^{* * *}\end{array}$ & $\begin{array}{l}0.174482 \\
(2.43)^{* *}\end{array}$ & 2.12 \\
\hline LDER & $\begin{array}{l}-0.11115 \\
(-2.40)^{* *}\end{array}$ & $\begin{array}{l}-0.098079 \\
(-1.74)^{*}\end{array}$ & $\begin{array}{l}-0.068561 \\
(-1.01)\end{array}$ & 2.14 \\
\hline Breusch Pagan LM Test & \multicolumn{2}{|c|}{$\begin{array}{l}425.23 \\
(0.0000)^{* * *}\end{array}$} & & \\
\hline
\end{tabular}

Hausman Test

1.81

$(0.6130)$

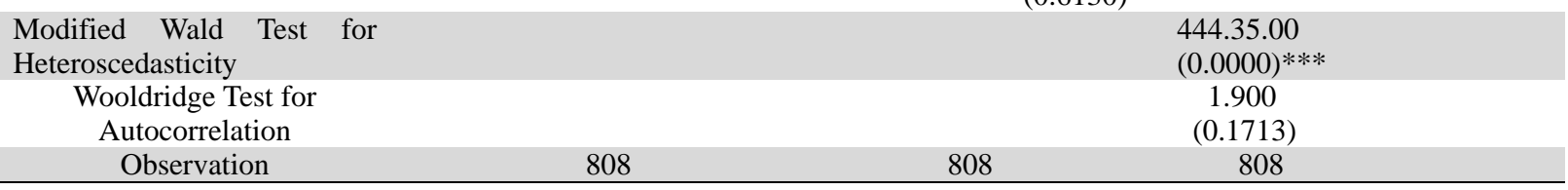

1. Figures in the parenthesis are t-statistic, except for the Breusch Pagan LM Test, Hausman Test, Heteroscedasticity and Autocorrelation Test which are the p-value.

2. Coefficient level: $10 \% *, 5 \% * *, 1 \% * * *$ 
The random effect model can be now constructed as $\mathrm{ROA}_{\mathrm{it}}=-4.2423+0.0664 \mathrm{COGS}_{\mathrm{it}}+0.1773 \mathrm{CAR}_{\mathrm{it}}-0.0981$ DER $_{\text {it. }}$

The random effects model above indicates that there is a positive impact between COGS and CAR on ROA. A one-percent increase in the cost of goods sold (COGS) will lead to $0.0664 \%$ increase in ROA of the firm. Another one percent increase in CAR will lead to $0.1773 \%$ increase in ROE. On the other hand, there is a negative impact in DER on ROA, with a one-percent rise in DER will reduce the firm's ROA by $0.0981 \%$. First, there is empirical evidence that the strong management of firm's fixed costs can improve profitability of the firm. The coefficient of the COGS sold is significantly and positively related to the firm's profitability that is measured by ROA with t-statistic of 2.26, and significant at $95 \%$. If a company's fixed portion of input is high when its sales are failing the profit margin will be stressed downward. The firm will be unable to cover its operating costs, giving rise to operating risk, which would lead to lower profitability. Thus, it is important for the management to manage the operating fixed costs in companies such as manufacturing, trading and services industry, as they quite often incur high fixed costs. Efficient management of fixed cost may potentially bring about firm performance. So, the firm should use their business assets efficiently in order to maximize their production and revenue to mitigate the threat of unavoidable fixed costs. Second, that proper management of liquid assets as measured by current assets coefficient can maximize firm's performance in term of profitability. In table 4 , it is noted that the coefficient of the CAR t-statistic of 2.76 is significantly and positively related to the profitability of the firm at $99 \%$ confidence level. The result concurs with the previous studies (Horne and Wachowicz, 2001) that firms with low current assets ratio will have more difficulty in continuing their operations. Firm with significant volume of liquid assets will not have to worry about borrowing as it has sufficient working capital for its daily use. Borrowing which may carry high interest rates, could be translated into high costs of doing business. Therefore, liquidity is important and should be managed continuously and effectively in order for the firm to meet its short-term obligations that will result in smooth business operation (Eljelly, 2004; Bhunia, 2010). Finally, a company with capital structure properly maintained can help to manage its debts effectively. The result from the study shows that there is a significant and negative impact of DER on ROA with a t-statistic of -1.74 at $90 \%$ confidence level. It means that firm with high debts tend to have lower profit. Damodaran (2001) suggested that the company source of financing would be from a good mix of debt and equity capital. A proper capital structure can influence a firm's performance and would affect the firm's health and its likelihood of default. However, the issue of proper capital structure has been a constant issue for discussion. Ross (1977), Heinkel (1982), Noe (1988), Champion (1999) and Hadlock and James (2002) suggest that high level of debts in the firm will lead to higher level of profitability. On the other side, studies by Kinsman and Newman (1998), Gleason, Mathur and Mathur, (2000) suggested that, in general, higher levels of debts will lead to lower firm performance. This result is consistent with the findings by Majumdar and Chibber (1999), Eriotis et al. (2002), Ngobo and Capiez (2004), Goddard et al. (2005), Rao et al. (2007), Zeitun and Tian (2007) and Nunes et al. (2009) that debt equity ratio is negatively and significantly related to performance showed in the regression results. If the firm uses more debts as the source of financing, it will tighten the performance of the firm and lead to more liabilities. This will thus increase the liquidity and financial risk of the firm. Therefore, the firm should balance its financing either with debt or equity to avoid the increase of bankruptcy costs that will lead to failure of business operation and increasing chance of default.

\section{Conclusion}

The primary aim of this study is to find out the effect of managing risk integration on the firm's performance. The risks are observed from the perspective of operation (operating risk), debt in capital structure (financial risk) and managing liquid assets (liquidity risk). It was observed that all the independent variables have either significantly directly or inversely affected the profitability of the firm. In other words, the operating risk, liquidity risk, and financial risk will have a direct influence on the firm performance in the trading service and consumer industry. An increase in cost of goods sold and current ratio by $1 \%$ will increase the return on assets by $0.06 \%$ and $0.18 \%$ respectively; while a decrease of $1 \%$ in debt-to-equity component will cause the return on assets to rise by $0.1 \%$. From operation perspective, managing operating risk is also indeed the arts of managing fixed costs that can improve business performance more effectively. Managing the firms' fixed cost is essential especially in the heavy industry such as trading, manufacturing, and services industry. This is because no matter how much revenue is made, the fixed costs of the firm which are fixed and unavoidable will affect the profitability of the firm. Companies with high volume of fixed costs are less flexible in responding to any changing business conditions. In a worst case scenario, like in an economic downturn, the business may face increased operating risk or financial pressure if it is unable to reduce the fixed costs as quickly as the drop in sales revenue. The firms with high fixed costs are by all means required to sell more to make up for their high 
fixed expenses in order to remain profitable. As evidenced in Claus and Daniel (2012) study, good operating risk management can potentially eliminate risks to improve business quality and cost. In the long run it may contribute to firm profits and shareholder wealth. Liquidity management is another important aspect in managing business to settle off any current obligations that include operating and financial expenses. Eljelly (2004) suggested that maintaining the appropriate level of liquidity is important in the day-to-day operation while meeting its obligations. The firm should ensure that it does not suffer from lack of liquid assess to meet its short-term pressures. Horne and Wachowicz (2000) found that firms with fewer current assets face difficulty in running their business operations, while excess of short term assets will result in lower return on investment. From financial perspective, the level of debts used by the firm as a source of financing remains a critical and mysterious issue on firm performance. There is no existing guideline on the optimal capital structure that a firm should follow (Myers, 2001). Firm with high level of debts is quite often associated with lower profit. Too much debt taken to finance the business can put the company over exposed to financial risk, which may lead to bankruptcy of the firm. Thus, a firm's specific strategy should have an appropriate mix of debt and equity in order to finance the firm's assets.

However, other risks are also important to be managed in a business in order to maximize the firm value and shareholder wealth at the same time. Therefore, it is stressed that top level management should not ignore the risk in the firm but get to know, understand and try to manage those risks to a minimum in order to attain better profitable position.

\subsection{Significance of the Study}

Risk need to be understood from a pragmatic approach and is significant to industry players. The study focuses on specific risk and explores the integration of these specific risks on firms' performance. Indeed, risk cannot be ignored in the firms' pursuit for profit. Therefore, it is stressed that top level management should not ignore the risk in the firm but get to know, understand and try to manage those risks to a minimum. This research nevertheless can form part of a framework for the management of the companies or investors in future operating, financial and investment decision.

It is essential for the firms to totally understand what kind of risks they are facing in order to minimize them. The study which focuses on trading service and consumer industry observed that operating risk is very important for management not to ignore, to maximize the firm performance. In investing strategy, investors are generally risk averse, whereby they are not willing to invest in high debt firm who may associate these firms with uncertainty and difficulty in meeting debts obligation. Therefore, investors are drawn more toward a less risky and stable investment. This research may motivate study in other developing countries in Asian region such as Singapore, Thailand, Cambodia and others, where risk management can be compared among these countries that will provide benchmarking and best practice of risk management approach.

\section{References}

Anup, A., \& Charles, R. K. (2012). Oxford handbook in managerial economics: Corporate governance and firm performance. New York: Oxford University Press.

Arthur, J. K. (2013). Personal finance: Turning, money into wealth (6 ${ }^{\text {th }}$ ed.). America: Cenveo.

Bhunia, A. (2010). A trend analysis of liquidity management efficiency in selected private sector indian steel industry. International Journal of Research in Commerce and Management, I(5), 213.

Braun, K.W., \& Tietz, W. M. (2015). Managerial Accounting, (4 ${ }^{\text {th }}$ ed.). London: Pearson

Chamberlain, T. W., \& Gordon, M. J. (1989). Liquidity, profitability and long run survival: Theory and evidence on business investment. Journal of Post Keynesian Economics, 11(4), 589-610. https://doi.org/10.1080/01603477.1989.11489765

Champion, D. (1999). Finance: The joy of leverage. Harvard Business Review, 77(4), 19-22.

Claus, H., \& Daniel, I. (2012). Operational risk management in practice: Implementation, success factors and pitfalls. A working paper, Version 1.2, November 2012.

Committee of sponsoring organizations of the Treadway commission (COSO). (2004). Enterprise risk management-integrated framework. London: New York.

Damodaran, A. (2001). Corporate finance: Theory and practice (2nd ed.). New York: Wiley.

Demsetz, H., \& Lehn, K. (1985). The structure of corporate ownership: Causes and consequences. Journal of Political Economy, 93(6), 1155-1177. https://doi.org/10.1086/261354 
Eljelly, A. (2004). Liquidity-profitability tradeoff: An empirical investigation in an emerging market. International Journal of Commerce \& Management, 14(2), 48-61. https://doi.org/10.1108/10569210480000179

Eriotis, N. P., Franguoli, Z., \& Neokosmides, Z. V. (2002). Profit margin and capital structure: An empirical relationship. The Journal of Applied Business Research, 18, 85-89.

Essinger, J., \& Rosen, J. (1991). Using technology for risk management. Retrieved from England.www.jisc.ac.uk/uploaded_documents/risk_assessment_guidance.doc

Gleason, K. C., Mathur, L. N., \& Mathur, I. (2000). The interrelationship between culture, capital structure, and performance: Evidence from European retailers. Journal of Business Research, 50(2), 185-191. https://doi.org/10.1016/S0148-2963(99)00031-4

Goddard, J., Tavakoli, M. \& Wilson, J. (2005). Determinants of profitability in European manufacturing and services: Evidence from a dynamic panel data. Applied Financial Economics, 15, 1269-1282. https://doi.org/10.1080/09603100500387139

Gorton, G., \& Rosen, R. (1995). Corporate control, portfolio choice, and the decline of banking. Journal of Finance, 50, 1377-1420. https://doi.org/10.1111/j.1540-6261.1995.tb05183.x

Hadlock, C. J., \& James, C. M. (2002). Do banks provide financial slack? Journal Finance, 57, 1383-1420. https://doi.org/10.1111/1540-6261.00464

Heinkel, R. (1982). A theory of capital structure relevance under imperfect information. Journal of Finance, 37, 1141-1150. https://doi.org/10.1111/j.1540-6261.1982.tb03608.x

Horne, V., \& Wachowicz, J. M. (2001). Fundamentals of financial Management $\left(11^{\text {th }}\right.$ ed.). Kuala Lumpur: Prentice Hall.

Hovakimian, A., Opler, T., \& Titman, S. (2001). The debt-equity choice. Journal of Financial and Quantitative Analysis, 36(1), 1-24. https://doi.org/10.2307/2676195

Jose, M. L., Lancaster, C., \& Stevens, J. L. (1996). Corporate returns and cash conversion cycles. Journal of Economics and Finance, 20(1), 33-46. https://doi.org/10.1007/BF02920497

Kinsman, M., \& Newman, J. (1998). Debt tied to lower firm performance: Finding calls for review of rise in debt use. Pepperdine University, Malibu: USA.

Larsson, C. G., \& Hammarlund, L. F. (2007). Cash Management för företag (9th ed.). Studentlitteratur, Lund.

Majumdar, S. K., \& Chibber, P. (1999). Capital structure and performance: Evidence from a transition economy on an aspect of corporate governance. Public Choice, 98, 287-305. https://doi.org/10.1023/A:1018355127454

Mehran, H. (1995). Executive compensation structure, ownership, and firm performance. Journal of Financial Economics, 38, 163-184. https://doi.org/10.1016/0304-405X(94)00809-F

Modigliani, F., \& Miller, M. H. (1963). Corporate income taxes and the cost of capital: A Correction. American Economic Review, 53(3), 433-443.

Mohsen, J., Arezoo, A. C., \& Vahid, B. (2011). Effective risk management and company's performance: Investment in innovations and intellectual capital using behavioral and practical approach. Journal of Economics and International Finance, 3(15), 780-786.

Myers, S. C. (2001). Capital structure. Journal of Economic Perspectives, 15(5), 81-102. https://doi.org/10.1257/jep.15.2.81

Ngobo, P. V., \& Capiez, A. (2004). Structure of capital on performance of the entreprise: The role moderator of differences culture. Congress of International Strategic Management Association, Le Havre.

Noe, T. (1988). Capital structure and signaling game equilibria. Review of Financial Studies, 1, 331-355. https://doi.org/10.1093/rfs/1.4.331

Nunes, P. J. M., Serrasqueiro, Z. M., \& Sequeira, T. N. (2009). Profitability in Portuguese service industries: A panel data approach. The Service Industries Journal, 29, 693-707. https://doi.org/10.1080/02642060902720188

Padachi, K. (2006). Trends in working capital management and its impact on firms' performance: An analysis of mauritian small manufacturing firms. International Review of Business Research Papers, 2(2), 45-58. 
Qasim, S., \& Razim, U. R. (2011). Impact of liquidity ratios on profitability: Case of oil and gas companies of Pakistan. Interdisciplinary Journal of Research in Business, 1(7), 95-98.

Rao, N. V., Al-Yahyaee K. H. M., \& Syed L. A. M. (2007). Capital structure and financial performance: Evidence from Oman. Indian Journal of Economics and Business, 7, 1-14.

Ross, S. (1977). The determination of financial structure: The incentive signalling approach. Bell Journal of Economics, 8, 23-40. https://doi.org/10.2307/3003485

Smith \& Stulz. (1985). The determinants of firm's hedging policies. Journal of Financial and Quantitative Analysis, 12(20), 391-405.

Stephanie, M. (2009). Risk management: Protect and maximize stakeholder value. An oracle governance, risk, and compliance white paper.

Stulz, R. (1996). Rethinking risk management. Journal of Applied Corporate Finance, 9(3), 8-24. https://doi.org/10.1111/j.1745-6622.1996.tb00295.x

Stulz, R. (2003). Rethinking risk management, The revolution in corporate finance ( $4^{\text {th }}$ ed.). United States: Blackwell Publishing.

Toh, R., \& Raven, P. (2003). Perishable asset revenue management: Integrated internet marketing strategies for the airlines. Transportation Journal. Retrieved from http://www.entrepreneur.com/tradejournals/article/108115104.html

Zeitun, R., \& Tian, G. G. (2007). Capital structure and corporate performance: Evidence from Jordan. Australasian Accounting, Business and Finance Journal, 1(4), article 3. Available at http://ro.uow.edu.au/aabfj/vol1/iss $4 / 3$

\section{Copyrights}

Copyright for this article is retained by the author(s), with first publication rights granted to the journal.

This is an open-access article distributed under the terms and conditions of the Creative Commons Attribution license (http://creativecommons.org/licenses/by/4.0/). 